\title{
Aleitamento materno
}

Breastfeeding

Viviane Gabriela Nascimento'

$\mathrm{O}$ artigo "Crenças alimentares no aleitamento materno. Um estudo entre gestantes e nutrizes atendidas em uma maternidade pública no município de São Paulo"1 mostra uma realidade que, muitas vezes, não é levada em consideração pelos profissionais da área da saúde em tentativa de se manter o aleitamento por um maior período. O conhecimento dos hábitos e costumes alimentares maternos e o que isso possa vir a interferir na amamentação pode se tornar importante ferramenta a favor de um aleitamento materno adequado.

Quando o assunto é aleitamento materno, torna-se muito importante conhecer os benefícios para a criança e a sua história, pois o homem tem interferido na prática natural do aleitamento materno desde a Antiguidade. A trajetória das práticas de amamentação mostra alterações no processo de aleitamento, que parece ter se modificado, não apenas como consequência de inovações científicas, mas também em função de determinantes econômicos, sociais e culturais de cada tempo e espaço geográfico, alternando momentos de suporte com momentos de desencorajamento à amamentação.

Já na Antiguidade buscavam-se métodos alternativos de alimentação quando a amamentação não era possível ou desejada pela mãe; nestes casos, a opção mais comum era a utilização de amas-de-leite. Durante os séculos XVII e XVIII, a adoção de amas-de-leite era feita por aristocratas e burguesas, que consideravam o ato de amamentar ridículo e repugnante, sendo esse comportamento tomado como exemplo pelas mulheres das classes menos favorecidas. Quando não era possível arcar com os custos de amas-de-leite, os bebês eram muitas vezes colocados diretamente nas tetas dos animais. A consequência da não amamentação resultava em altíssimos índices de mortalidade infantil ${ }^{2}$.

No século XIX, quando se percebeu a relação direta entre a falta de aleitamento e mortalidade infantil altíssima, os médicos da época decidiram encorajar a amamentação, e o aleitamento materno passou a ser considerado um poderoso meio de sobrevivência infantil; sendo assim, as mães passaram a ser obrigadas a aleitar para zelar pela saúde de seu filho. Um novo decréscimo da amamentação iniciou no Brasil na década de 1940 e chegou ao seu apogeu na década de 1970: a mãe desapareceu como nutriz, surgindo as mamadeiras, e os médicos tornaram-se responsáveis pela orientação da amamentação dos bebês ${ }^{3}$.

A partir de 1981, com a Campanha Nacional de Incentivo ao Aleitamento Materno, houve progressiva melhora dessa situação no país. Em 1986, a nível internacional, ocorreu importante marco referencial na história da amamentação, na Assembleia Mundial de Saúde, quando foi votado que “doações de substitutos de leite materno, são desnecessárias as maternidades”, definindo também que os "leites de seguimento" são desnecessários. Em 1989, a Organização Mundial de Saúde lança um documento que se pode reputar como fundamental, hoje, em qualquer atividade programática: a “Declaração Conjunta sobre o Papel dos Serviços de Saúde e Maternidades”, em que se relacionam dez ações para incentivar o aleitamento materno ${ }^{4}$.

A Organização Mundial de Saúde, em 1990, recomendou que as crianças fossem amamentadas exclusivamente ao seio até os quatro a seis meses de vida e que o aleitamento materno continuasse pelo menos até os dois anos de idade ${ }^{5}$ e, em 1992, classificou o aleitamento em: aleitamento materno exclusivo (quando a criança recebe somente leite materno e nenhum outro sólido ou líquido, com exceção de xaropes de vitaminas, minerais e/ou medicamentos), aleitamento materno predominante (quando a criança recebe, além do leite materno, água ou bebidas à base de água, como suco de frutas e chás) e aleitamento materno (quando a criança recebe leite materno, independentemente de estar recebendo qualquer alimento ou líquido, incluindo leite não humano) ${ }^{6}$.

Em 2001, a Organização Mundial de Saúde propôs que a duração do aleitamento materno exclusivo fosse até o sexto mês de vida e que a amamentação deveria ser mantida por pelo menos dois anos?

Nas últimas três décadas, aconteceram avanços importantes para a prática do aleitamento materno no Brasil, mas apesar dos incentivos ao aleitamento materno, o Brasil ainda não conseguiu atingir as recomendações da OMS. Segundo o relatório do Ministério da Saúde ${ }^{8}$, a prevalência do aleitamento materno exclusivo em menores de seis meses foi de $41 \%$ e em crianças de nove a 12 meses a prevalência de aleitamento materno foi de $59,7 \%$, ambas as prevalências no conjunto das capitais brasileiras.

\footnotetext{
1 Departamento de Saúde Materno-Infantil da Faculdade de Saúde Pública da Universidade de São Paulo (USP) - São Paulo (SP), Brasil. Endereço para correspondência: Viviane Gabriela Nascimento - Departamento de Saúde Materno Infantil - Avenida Dr. Arnaldo, 715 - Cerqueira César CEP: 01246-904 - São Paulo (SP), Brasil -E-mail: vivianegnasc@hotmail.com
} 
Em relação aos benefícios à criança, é indiscutível que o aleitamento materno representa forma natural e adequada de alimentação nos primeiros meses de vida, propiciando crescimento e desenvolvimento adequado?. O leite materno tem, em relação aos outros leites, vantagens importantes para a saúde da criança, pois é nutricionalmente superior, é bacteriologicamente seguro e sempre fresco e fornece à criança fatores anti-infecciosos e antiinflamatórios. O aleitamento materno propicia outros benefícios, como o aumento à imunidade da criança e proteção contra infecção gastrointestinal e respiratória ${ }^{10}$.

O aleitamento materno exclusivo até o sexto mês de vida é o ideal, pois a introdução precoce de outros alimentos interfere negativamente na absorção de nutrientes e em sua biodisponibilidade, levando a uma menor ingestão do leite, menor ganho ponderal e ao aumento do risco de diarreias, infecções respiratórias e alergias. A interrupção precoce do aleitamento materno exclusivo pode levar a ingestão energética inadequada? .

Apesar da maior difusão do conhecimento de que o aleitamento materno, oferecido de forma exclusiva, atende as necessidades de energia e nutrientes do lactente até cerca de seis meses de vida, verifica-se a interrupção deste ainda muito cedo, o que pode ocorrer, muitas vezes, por crenças e tabus de uma população. Devido à importância e benefícios do leite materno à criança nos primeiros meses de vida, muitos estudos são realizados para verificar a prevalência, frequência e duração da amamentação, porém poucos revelam o porquê do insucesso da amamentação e como intervir nesse processo.

Os resultados deste estudo mostram um dado muito importante, que é a preocupação das gestantes e nutrizes com o sucesso da amamentação, caracterizando que o entendimento sobre os benefícios do leite materno à saúde da criança está cada vez mais presente na população. Outro fato importante é o das entrevistadas mencionarem como benefícios para a lactação a ingestão de frutas, verduras e legumes, leite e derivados, líquidos e feijão, o que mostra que as mães associam uma alimentação adequada como forma de auxiliar na lactação.

Uma vez conhecidos os principais tabus e crenças existentes ainda hoje, em parte da população, deve-se pensar em iniciar um trabalho educativo de maneira a auxiliar gestantes e nutrizes a quebrar esses preconceitos em relação à amamentação.

Uma educação nutricional, baseada em uma alimentação equilibrada tanto para as gestantes como para as nutrizes, levando-se em consideração também a importância do aleitamento materno e uma alimentação complementar adequada para a criança, pode caracterizar uma ferramenta importante no auxílio do sucesso do aleitamento materno.

\section{Referências}

1. Oliveira DR, Gomes PR, Bando AMN, Gonçalves SR. Crenças alimentares no aleitamento materno. Um estudo entre gestantes e nutrizes atendidas em uma maternidade pública no município de São Paulo. Arq Bras Cienc Saúde. 2011;36(2):67-71.

2. Silva IA. Amamentar: uma questão de assumir riscos ou garantir benefícios. São Paulo: Robe Editorial;1997.

3. Borges ALV. Opinião de mulheres de uma unidade de saúde da família sobre a quantidade de leite materno produzido. [Dissertação de Mestrado]. Faculdade de Saúde Pública da USP. São Paulo: 2000.

4. Rea MF. Reflexões sobre amamentação no Brasil: de como passamos a 10 meses de duração. Cad Saúde Pública. 2003;19(Sup1):S37-45.

5. World Health Organization. Breastfeeding and use of water and teas. Geneva: World Health Organization; 1991.

6. World Health Organization. Indicators for assessing breastfeeding practices. Update. Programme Control Diarrhoreal Dis. 1992.

7. World Health Organization. Global strategy for infant and Young child feeding. 54th World Health Assembly. Geneva: World Health Organization; 2001; A54-7.

8. Ministério da Saúde. II Pesquisa de prevalência de aleitamento materno nas Capitais Brasileiras e Distrito Federal. 2009. Disponível em: htttp//portal.saude.gov.br. Acesso em: 20 jun. 2011.

9. Kramer MS, Chalmers B, Hodnett ED, Sevkovskaya Z, Dzikovich I, Shapiro S, et al. PROBIT Study Group (Promotion of Breastfeeding Intervention Trial). Promotion of Breastfeeding Intervention Trial (PROBIT): a randomized trial in the republic of Belaurs. JAMA. 2001;285(4):413-20.

10. Aidam BA, Pérez-Escamilla R, Lartey A. Lactation counseling increases exclusive breast-feeding rates in Ghana. J Nutr. 2005;135(7):1691-5. 